\title{
EMPLOYEE TALENT IN DEVELOPMENT OF ORGANIZATION
}

\author{
Kazimierz, Jaremczuk ${ }^{\mathrm{a}}$ \\ Anna Mazurkiewicz ${ }^{\mathrm{b}}$
}

Subcarpathian Association of Organization and Management

a e-mail: kazimierzjaremczuk@gmail.com, b e-mail: an_nam@onet.eu

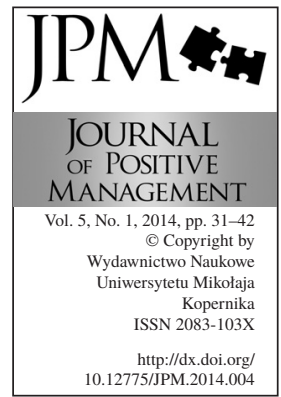

\begin{abstract}
The changes in the environment of the organization, particularly globalization, and changes in the demographics, as well as changes in the expectations and requirements of employees or customers, cause that current solutions are inadequate to the new conditions of operation, resulting in the inefficiency and ineffectiveness. Organizations must therefore constantly improve their operations. This requires a new approach, including one in human resource management, which is particularly a challenge to the best performing employees with great potential or talented employees. The ability to attract and retain talent in the organization is important for the ongoing operation and development of the organization.

The purpose of this study is to show the importance of talent in the development of the organization. This objective required the identification of the conditions of interest and talent in the organization to a multi-faceted understanding of the concept of talent (with particular emphasis on the organizational aspect). It also drew attention to the issue of the development of talent. Contemplations have been carried out in the context of the organization.
\end{abstract}

Keywords: subjectivity, spirituality, talent, gift, innate talent, organizational development

Paper type: Conceptual paper

\section{Introduction}

The conditions in which modern organizations function cause that the fundamental mindset of managers focuses not only on material aspects, but also on problems which have no material basis, in majority those connected with the spiritual area of an organization.

Complex and unpredictable environment fuels the search of new ways in achieving steady and continuous advantage on the globally competitive market. Educated employees are less likely to accept the usage of past solutions connected with the structure and organization of work. In addition, these same workers consider those approaches to be unattractive or inadequate to the level of knowledge or skills they possess, and treat them as less effective. At the same 
EMPLOYEE

TALENT

IN DEVELOPMENT

Kazimierz Jaremczuk

Anna Mazurkiewicz time a question arises about how their education and possessed skills fit in with the goals or values of a prospective employer.

It is necessary to focus on aspects which will make it feasible to fulfil goals of these organizations, quantifiable or qualitative alike, and also on the employed staff itself. The key factor is the talent management (Strack et al., 2010) and this is what the organizations should concentrate on in order to face up to the challenges of their surroundings. Acquiring the skill of recognizing one's talent development in this context is very crucial. Therefore, the specification of individuals we should consider to be talented and what characterization features make a talented employee, are also necessary.

The role of talented employees is particularly important in the development of the organization, which is interpreted differently- the concept is hardly measurable category it is relative (Białasiewicz, 2002). The development of the organization is defined as occurring during the process of change (Machaczka, 1998,), as a result of which the state or more complex or more perfect form is reached, characterized by new properties.

This phenomenon is most frequently explained by quantitative concepts and measures of development (Konecki, 2007; Bolesta-Kukułka, 1997). However, the development of the organization relates to changes both quantitative- objective and taking place in these areas, which are not measured- in social relations, in the behavior and attitudes of employees. Both areas are closely interrelated and interact with each other (Kalin, 1998). According to J. Penc, development is a qualitative and quantitative changes' oriented process (structural changes, technological, cultural, etc.), trending relatively persistent, favoring the survival and stability of the organization (Penc, 1997).

In this hereby formulation, a comparison test of what the relation of talent to the development of organization was conducted. For this purpose the premises of the interest in organizational talent were indentified, with the multi-aspect interpretation of the concept of talent, and strong emphasis on the scale of the organization, in which the attention was placed on the factor of talent development. Subjective speculations were focused on the context of the organization's growth and were based on the national and international literature used in management studies.

\section{Premises of interest in talent}

When identifying the challenge premises of organizations, it is crucial to focus on the characteristics of the ,future company” model created by L. Strannegard and M. Friberg. In this concept, the liquidity and instability in this future company is very common, and in some instances obvious. The employees are educated and it is very common that their education isn't directly connected with the type of work they do. They are uncomfortable in traditionally structured professions, 
but are strongly in the need of rigid and varied work. These employees come ideas of management. Organization's management assumes the diversification and acceptance of changes, complexity and multifacetedness. It is believed, according to L. Strannegard and M. Friberg that we are heading in the direction of accepting new ways of managing companies or corporations. And this is not only in the way of companies which are optimal in connecting innovation with profitability, but also in the approach of management, in which the boundaries between innovation and profits or fun, seriousness and free time, will be eradicated (Kostera, 2008) [1]. In addition, as M. Romanowska points out, the ideal of the future company or corporation is the ,intelligent innovator" - a company which is not too great in size, but which has the intellect reserves difficult to copy and predispositions for proactive shaping or moulding of its model of operations. A company like this can not only successfully catch up to its fleeing added value, but because of its excellent architecture and reputation, it collects parts of this added value from other, less intelligent market participants (Romanowska, 2009).

This previously mentioned standpoint of L. Strannagard, M. Friberg, and M. Romanowska suggests that the employees possess a strong need of creative and varied work, and this strength is based on changes, complexity and the multifacetedness. The leadership of this future company, efficient in new ideas of management, will optimally connect entrepreneurism, innovation, and profitability. These instances, directed at the utilization of company's wealth bring out the described capabilities of management. If we take M. Depree into consideration, it is possible that the skill of connecting unforeseen future and the talents of prospects is a very significant challenge for an upcoming manager (Aniszewska, 2006).

In the extent of unpredictable future J. Rokita proclaims, that the environment of an enterprise is under the influence of feedback, in the course of which, the system operates on the verge of stability and instability, generating behavioural algorithms or models, which are irregularly changeable, or therefore unforeseeable. This is why we are dealing with random change of behaviour and unpredictable future. The described system is disorganized and on the verge of chaos (Rokita, 2007). B. Nogalski and H. Marcinkiewicz are of similar mind, when stating that the supporters of this ,chaos theory" think that the development and growth takes place through exploitation of current events or situations. There is no reference point and therefore it is difficult to deduce if any progress in development is made. It is also the reason why we allow the notion to cease this current way of operating the enterprise in order to create new opportunities or new possibilities (Nogalski and Marcinkiewicz, 2004).

The cessation of this past approach is achievable through the exploitation of talents in the process of functioning and development of the organization. 
EMPLOYEE

TALENT

IN DEVELOPMENT

Kazimierz Jaremczuk

Anna Mazurkiewicz
M. Brzezinski forms one of the proposals in this regard, stating that new and efficient way of managing requires transformation of this contemporary architecture of problem management through the replacement of methods based on mental processes, controlled by rational intelligence and methods which include emotional intelligence, as well as a spiritual one. In the rational approach, the mind decides on the assumptions and goals, but the emotional/spiritual way is based on accepting the inner guidance, which is contained in subjectivity.

Proposed as a consequence of the substitution process of rational intelligence, emotional intelligence and spiritual supremacy of knowledge aimed at qualitative (quiet, hidden) in the management of the organization. Consequently, the recognition of a paradigm of creativity coexists in mutual relations with the paradigm of spirituality [2]. The paradigm that does not have a single theory so far, notes M. Izak (Izak, 2008). Today we lack an answer to the question: Is it possible to treat spirituality as an aspect of the operation, in which the organization has the right to freely influence, or rather should it be examined and summarized without any interference?

Paradigm's cognitive area of spirituality can be shaped, among all, by the current formulated definitions of spirituality (Izak, 2008):

- dimension of human life that goes beyond the biological, psychological and social aspects,

- the search area, asking of important questions, sensitivity, openness, softness and flexibility in their lives,

- the strive for a specific state of mind, which is more perfect. This selfdevelopment, search for perfection.

In addition, the cognitive area's paradigm of spirituality can identify the experience of Xerox Company, which takes care of its development and places particular emphasis on the internal development of its employees. This organization sends its workers to desert areas of New Mexico to ponder and to deeply reach inside, in order to draw out inspirations for the introduction of new technologies, and thus help build a successful organization. Similar examples found in the practices used by employees of the World Bank, Pizza Hut, Taco Bell, and others. Reaching into their employees, these organizations represent a visible relationship between spirituality and the functioning of a modern organization (Izak, 2008).

\section{Concept of talent}

The concept of talent has not yet been clearly defined, which has significant implications for organizational performance, especially in the process of talent management. Clarifying the definition of talent is not an easy task because there are many aspects in this concept. The starting point for further considerations is to provide its etymological meaning. 
The first definition of talent refers to denomination of weight, used by the Assyrians, Babylonians, Greek, Romans, and other ancient nations. When value was attributed to one talent of silver, talent became a monetary unit. The widespread use of the notion talent was introduced by the Bible [3]. By the thirteenth century this word was related to an inclination or a disposition. In the fifteenth century it denoted treasure, riches, mental endowment and natural ability, and then - by the seventeenth century - related to a special, natural ability or aptitudes and faculties of various kinds. By the nineteenth century, talent was also viewed as embodied in the talented (Tansley, 2011).

Today's talent stands for extraordinary, outstanding creative ability and remarkable skill. Talent can also be referred to a man gifted with such abilities and features (Doroszewski, 1967; Stownik wyrazów..., 1995). Some definitions emphasize that it is an innate predisposition for something (Słownik wyrazów..., 2012). Talent can be interpreted in terms of attribute-based, as a remarkable skill, exceptional creative ability, or subject, in relation to a man endowed with these outstanding abilities (Jamka, 2011).

Presented by these definitions appears, that talent is an important component of work. Creative attitude- which consists of a transforming reality and at the same time transforming a human [4]- awakens the inner strength, inspires, grabs, and lifts, giving the opportunity to fulfil oneself at living in today's world (Suchodolski, 1974). Creative skills do not only depend on the resource of human intelligence, special talents or abilities, but creativity is seen as the general attitude towards the world and the belief that it can work towards achieving the ideals of excellence [5].

At the same time work is part of the modern ideal of a person. This ideal is not very professional in nature; it can only be an ideal for a complete individual (Bierdiajew, 2006). The modern ideal of a person is thus associated with the teaching of talents. This ideal directs the proceedings to perfection. T. Kotarbiński associates the ideal with moral self-management, and therefore the ideal is the guiding principle as the standard of the organization's own life (Powszechna..., 2003). The ideal is a pattern; the talent is therefore a pattern, in the organization alike.

Given the purpose of this study, it is also necessary to clarify the concept of talent in the organization. The organization of this concept can be defined at three levels: organizational, group and individual. Considering the first level, it is important to emphasize that each organization defines talent having regard to its specificity, and therefore the functioning and development. The ambiguity of the definition of talent is clear from the diversity of organizational needs. Moreover, it is a dynamic concept and changes over time depending on the organization's objectives. 
EMPLOYEE

TALENT

IN DEVELOPMENT

Kazimierz Jaremczuk Anna Mazurkiewicz
At the individual level, talent is referred to as exceptional and unique. Individual authors define the concept of talented people differently, pointing to its specific features. When analyzing the presented literature definitions, it is clear that "talent" is a person with outstanding ability, extensive knowledge and skills in a specific area. A person who is creative, entrepreneurial, strongly committed to work, one that takes care of his/her own development. A talented person achieves outstanding results, has a high potential, and thus significantly affects the current operation, additionally the development of the organization. Loss or absence of talent strongly inhibits the growth of the organization because of its disproportionate impact on current and future performance (Berger, Berger, 2004). Talent refers primarily to the individual, but its definition has consequences on a group level as well.

On the group level the paradoxical nature of talent is reflected. This concept has a positive meaning - talent is the value of the organization, its attributes; but at the same time negative - ,marginality" employee talent - to be the best, is associated with frustration of colleagues and has an impact on the results. This raises the question - to what extent, will this talented employee be able to collaborate without any fears of alienation? Therefore, as M. Crozier concludes, the promotion and development of individualism in collectives is the essence of any person being truly free and autonomous in his/her decisions? With this the author affirms a persona of an employee because of an ability to innovate, the ability to create services and aspirations to higher quality.

It should also be noted, as in regards to F. Hayek, that spontaneous cooperation of free people creates bigger things than their individual minds are able to sufficiently comprehend. People left alone to themselves, often achieve more than what the individual mind could design and predict (Hayek, 1998). Therefore, staying outside of F. Hayek's imperative leads to the destruction of spontaneous collaboration of free people.

Conducted contemplations show that the concept of talent is the relativistic nature, because it is important how a person becomes aware of certain things, rather than how reality reflects it. As a result, a person always interprets the specified term, including the concept of talent, so he/she can afford his education, culture, knowledge, experience and expectations. The problem with a transparent clarification of the definition of talent arises due to the fact that the assessment must be carried out in the context of formal or informal structure in which it is tested. It does not, therefore, carry the absolute content; the rating is identical and independent of its context. This assessment depends on the assumptions, beliefs or cultural grounds (organization's models in practice, formulated targets). 
Having spiritual gifts - talents that are innate, is necessary to become a talented individual - one cannot be talented without being gifted (Gagné, 2000) [6]. Talent can not be created, but it can be expanded, improved or destroyed (Kwiecień, 2004).

Talent emerges progressively from the transformation of the aptitudes into the systematically developed skills. Natural abilities or aptitudes act, therefore, as ,raw material” - in other words - constituent elements of talent. The talent development accomplishes, when the person engages in systematic learning and practicing process. This process is facilitated by two types of factors intrapersonal and environmental (Gagné, 2000).

A.J. Howe writes about innate talent, enumerating its following features (Howe et al., 1998):

a) Talent originates in genetically transmitted structures, what signifies it is at least partly innate.

b) Its full effects may not be evident at an early stage, but there will be some advance indications, allowing to identify the presence of talent of a person, before it will be achieved by her exceptional - above average performance.

c) These early indications of talent provide a basis for predicting who should be developed.

d) Minority is talented.

e) Talent is domain-specific.

However, in order to be judged as gifted, and therefore participate in the process of talent development, a person needs, according to R.J. Sternberg, to meet five criteria (Sternberg, 1993):

- excellence, which states that gifted persons are superior to their peers in some dimension or set of dimensions,

- rarity, according to which gifted persons must demonstrate a high level of an attribute that is rare amongst their peers,

- productivity, which is used concerning gift assessment. According to this criterion, gift assessment should concern the dimensions, which lead or potentially lead to productivity,

- demonstrability - an individual's superiority must be demonstrable through one or more tests that are valid assessments,

- value - gifted person must show superior performance in a dimension that is valued by the society. 
EMPLOYEE

TALENT

IN DEVELOPMENT

Kazimierz Jaremczuk

Anna Mazurkiewicz
From the conducted contemplations it is concluded that talent must be genetic. Genetic factors are necessary, but not sufficient to reveal talent. Moreover, conditions which enable the elicitation and this talent's development are also necessary.

It is crucial to multiply and develop talent in the organization, because, as the Evangelist Matthew writes, ,For unto every one that hath shall be given, and he shall have abundance: but from him that hath not shall be taken away even that which he hath" (Pismo..., Mt 25, 14-30). From the presented Gospel parable, it is believed, that the multiplication of talents is associated with joy (,Rejoice with your Lord!'), and hiding it will cause impoverishment, but also condemnation (,And cast ye the unprofitable servant into outer darkness: there shall be weeping and gnashing of teeth") [7].

This situation has been recognized by R.K. Merton to accumulate prestige and authority in the world of science and academia, defined as „St. Matthew Effect” (Merton, 1968). Today, this issue is also recognized in other aspects of life, such as education, household income, economic development, and as per organization career issues, employee productivity and organizational development (Bothner et al., 2010).

R.K. Merton which writes with accordance to K.T. Konecki, explains that the structural phenomenon presented, focuses on the multiplication of resources [8]. The question of talent is a complex issue, so it is important to look for other conditions of multiplying talents of some individuals, and the impoverishment of others. On the basis of investigations, it can be concluded that these are factors relating to the individual and his/her environment. In addition to the inheritance of certain traits, the biographical context of the individual and their perception of themselves is also important, not forgetting their high self-esteem (Konecki, 2008, p. 412).

Talent- as a person with great potential, achieve above-average results, but also is characterized by specific features, capabilities. Talent is therefore a person of outstanding ability. The ability, in accordance with the model J.S. Renzulli, is formed by:

- above-average ability, i.e. the general ability, and ability-specific, related to specific areas and associated with specific activities,

- creativity - originality and novelty denoting ideas, their generation, as well as flexibility and originality of thinking, the ability to take on new problems and risks, sensitivity, high emotionality and openness to ambiguity,

- work engagement, related to determinants of personality. Personality determines the perseverance, determination of aspiration for purpose, conviction about own capabilities, criticism resistance, fascination with the work, which is typical for people with outstanding achievements. 
The high quality of the action and outcome depends primarily on intelligence and creative abilities. While motivation, associated with personality, determines the direction and consequences of actions (Sękowski, 2004). Talented employees, particularly in managerial positions, affect significantly the organization development - they shape the potential of the organization, are also "driving force" of the team and the organization as a result i.a. taking on challenges and creative solutions to the difficulties, as well as the result of an ongoing commitment to development.

Therefore, talents must be multiplied or developed - in the development of contemporary organization the role of its potential as a source of competitive advantage is emphasized, while pointing the importance of innovation out. Substantial are still traditional functions (financial, production, personnel, marketing, etc.), but the significant role is played by processes, such as knowledge management, creativity management, competency management, talent management (Mikuła, 2001). The properties make talent a factor that can support the development of the organization, being its strength.

A person, as Bierdiajew writes, should fight for the fulfilment of his/her creative vocation in spite of the reality connected with society, family, economy, or politics (Bierdiajew, 2006). Although this leads to many conflicts with the clash of different reality values, it is a struggle not for selfish interests, but for the ideal image of a creator. This creative way, while being selfless and filled with suffering, is always liberation from captivity (Bierdiajew, 2001), and therefore as a consequence of the development of a specific structure, brings it to perfection.

\section{Conclusion}

The development of the organization is accomplished by empowering employees through concretization and realization of their abilities. Subjectivity constitutes a manifestation of the will to act and the dignity of the worker. They are regarded as creators of the development in the organization and not only as parts of it. An employee, which is a creator, perceives an organization in the process of its development. This employee does not bury his/her talent in the ground, but realizes it through the real growth of the organization, thereby becoming a cofounder/creator of organizational development. And thus, this person objectifies thanks to his/her talent.

Talent is a predisposition, and therefore contributes to creation of work.

\section{Notes}

[1] Anticipated reduction in the boundaries between work and leisure tends to reflect on the experience of subjectivity, and which teaches - according to the standpoint of E. Lévinas - that the human thoughts are based on the needs, which are expressed by the society and history; and that hunger or fear can overcome all human resistance and all freedom (Levinas, 2002). The experience of 
EMPLOYEE

TALENT

IN DEVELOPMENT

Kazimierz Jaremczuk Anna Mazurkiewicz subjectivity, therefore, teaches that the human mind, based on the needs where fear and hunger are the genesis, is determined not only by erasing the boundaries between work and leisure, but also between rich and poor, for which the hedonistic criteria are decidedly of subjective nature. Dualism declaration (e.g. empowerment) and facts (such as wealth and poverty) are both a motivation to change the status quo (for the poor and not only), but therefore, also create profound reflection on the possibility of losing the status quo (e.g. wealth).

[2] Spirit is an essential component of reality, communicable as a ,gasp", which is the source of life; a simple intangible element, the principle of unifying, ordering and animating, an essential element, the type of substance - an intangible personal being, a being capable of consciousness, cultural value, entity or part of the psyche - the mind, soul, thought, psychic energy, power, courage, bravery (Powszechna..., 2001).

[3] This issue will be subjected to further analysis in this report.

[4] "As long as nothing creaks in our picture of the world and no sounds of any dissonance are detected, as long we are not bombarded with contradictions, conflicts and problems, with no surprises and no worries- they will not find any valid reason to change the current view of the world, and therefore create a new image of it. It seems that a starting point is necessary for any creative changes or any real justification" (Malicka, 1982). Creativity is the way of the unknown, it is also a way of opposing the tyranny of the routine view of the world and it is a procedure of its decomposition, the deconstruction of mental habits is always a new look on the world, "the wonder of what is 'is not difficult', is a matter of creation, and looking anew is a question of genius and courage" (Malicka, 1982).

[5] Excellence is the highest level of positive features, the lack of any defects (Doroszewski, 1965), the supreme act of being, acting in accordance with the nature or design of the Creator or author (Powszechna..., 2001). With the spread of Christianity, there was a dispute over whether human perfection is attainable. Excellence was attributed only to God, what an ordinary man could only strive for. W. Glencoe concludes that true excellence depends on continuous improvement, replenishment, enrichment. If the world was so perfect that there would be no room for new things, then it would not be most perfect- so if it was perfect, it would not be perfect. For Aristotle perfection equals completion. For Empedocles perfection consists of insufficiency because it creates the opportunity to develop and enrich new features, the perfection of art is how to get the recipient to be active, to supplement the work effort of intellect and imagination (Tatarkiewicz, 1976).

[6] The ability can be simply and directly observed in young children, because the impact of the environment and the process of learning have a „calming” effect, which is rather minor.

[7] The servant in the parable of St. Matthew, who received the most talent and multiplied it, gained the favor of their Lord. The one who received less talent, had also multiplied it, and had therefore been praised. However, the servant who retained and sustained the talent which he had been given, was damned.

[8] Having a set of resources in the academic world, such as prestige, you can receive additional resources in terms of authority, popularity, but also the nature of the material - awards, grants and others. This situation results in further enrichment of those who already have the resources and who as a result of the growth of prestige and popularity, gaining greater authority, cause the relative impoverishment of those who do not have such resources. People belonging to the second group are less noticed, and therefore have a lesser chance of attaining various rewards. These individuals therefore become ,poorer".

\section{References}

Aniszewska, G. (2006), „Innowacyjne zarządzanie”, Przegląd Organizacji, No. 3, pp. $45-47$. 
Berger, L.A., Berger, D.R. (2004), The talent management handbook: creating organizational excellence by identifying, developing, \& promoting your best people, McGrawHill, New York.

Białasiewicz, M. (Ed.) (2002), Rozwój przedsiębiorstw. Modele, czynniki, strategie, Wydawnictwo Naukowe Uniwersytetu Szczecińskiego, Szczecin.

Bierdiajew, M. (2006), O przeznaczeniu człowieka. Zarys etyki paradoksalnej, Wydawnictwo Antyk, Kęty.

Bierdiajew, M. (2001), Sens twórczości, Wydawnictwo Antyk, Kęty.

Bolesta-Kukułka, K. (1997), „Świat organizacji”, in: Koźmiński, A.K., Piotrowski, W. (Ed.), Zarzqdzanie. Teoria i praktyka, Wydawnictwa Naukowe PWN, Warszawa.

Bothner, M.S., Haynes, R., Lee, W., Bishop Smith, E. (2010), „When do Matthew Effect Occur?", Journal of Mathematical Sociology, Vol. 34, pp. 80-114.

DOI: 10.1080/00222500903310960

Brzeziński, M. (2006), ,Zdążanie ku nowemu zarządzaniu”, Przegląd organizacji, No. 10. Doroszewski, W. (Ed.) (1967), Stownik języka polskiego, t. IX, PWE, Warszawa.

Gagné, F. (2000), „Understanding the Complex Choreography of Talent Development”, in: Heller, K.A., Mönks, F.J., Sternberg, R.J., Subotnik, R.F. (Ed.), International Handbook of Giftedness and Talent, Elsevier, Oxford, pp. 67-80.

DOI: 10.1016/B978-008043796-5/50005-X

Hayek, F. (1998), Indywidualizm i porzq̨dek społeczny, Znak, Kraków.

Howe, M.J.A., Davidson, J.W., Sloboda, J.A. (1998), „Innate talents: reality or myth?”, Behavioral and Brain Sciences, Vol. 21, pp. 399-442.

DOI: $10.1017 / \mathrm{S} 0140525 X 9800123 \mathrm{X}$

Izak, M. (2008), „Duchowość w organizacji”, in: Kostera, M. (Ed.), Nowe kierunki w zarzadzaniu. Podręcznik akademicki, Wydawnictwo Akademickie i Profesjonalne, Warszawa.

Jamka, B. (2011), Czynnik ludzki we wspótczesnym przedsiębiorstwie: zasób czy kapitat?, Wolters Kluwer, Warszawa.

Konecki, K.T. (2008), „Zarządzanie talentami - zarządzanie lamentami”, czyli jak rozwija się „geniusz”?”, in: Banaszak, S., Doktór, K. (Ed.), Problemy Socjologii Gospodarki, Wydawnictwo Wyższej Szkoły Komunikacji i Zarządzania, Poznań, pp. 411-427.

Kostera, M. (Ed.) (2008), Nowe kierunki w zarządzaniu. Podręcznik akademicki, Wydawnictwo Akademickie i Profesjonalne, Warszawa.

Kwiecień, K. (2004), „Zarządzanie talentami w międzynarodowych korporacjach”, in: Borkowska, S. (Ed.), Zarządzanie talentami, IPiSS, Warszawa.

Lévinas, E. (2002), Całość i nieskończoność. Esej o zewnętrzności, PWN, Warszawa.

Machaczka, J. (1998), Zarządzanie rozwojem organizacji, Wydawnictwo Naukowe PWN, Warszawa-Kraków.

Malicka, M. (1982), Uroki i trudy twórczego życia, Wydawnictwo Nasza Księgarnia, Warszawa.

Merton, R.K. (1968), „The Matthew Effect in Science”, Science, Vol. 159, pp. 56-63. DOI: $10.1126 /$ science. 159.3810 .56

Mikuła, B. (2001), Elementy nowoczesnego zarządzania. W kierunku organizacji inteligentnych, Antykwa, Kraków. 
EMPLOYEE

TALENT

IN DEVELOPMENT

Kazimierz Jaremczuk

Anna Mazurkiewicz
Nogalski, B., Marcinkiewicz, H. (2004), Zarzadzanie antykryzysowe przedsiębiorstwem. Pokonać kryzys $i$ wygrać, Difin, Warszawa.

Penc, J. (1997), Leksykon biznesu, Agencja Wydawnicza Placet, Warszawa 1997.

Pismo Święte Starego i Nowego Testamentu (1999), Księgarnia Świętego Wojciecha, Poznań.

Powszechna Encyklopedia Filozofii (2001), Vol. 3, Polskie Towarzystwo Tomasza z Akwinu, Lublin.

Powszechna Encyklopedia Filozofii (2003), Vol. 4, Polskie Towarzystwo Tomasza z Akwinu, Lublin.

Rokita, J. (2007), „Planowanie strategiczne a nieprzewidywalność zmian warunków funkcjonowania organizacji”, in: Krupski, R. (Ed.), Planowanie strategiczne w warunkach niepewności, Wałbrzyska Szkoła Zarządzania i Przedsiębiorczości, Wałbrzych.

Romanowska, M. (2009), Planowanie strategiczne w przedsiębiorstwie, PWE, Warszawa.

Sękowski, A.E. (2004), „Psychologiczne uwarunkowania wybitnych zdolności”, in: Sękowski, A.E. (Ed.), Psychologia zdolności. Wspótczesne kierunki badań, Wydawnictwo Naukowe PWN, Warszawa.

Słownik wyrazów obcych (1995), Wydawnictwo Naukowe PWN, Warszawa.

Słownik wyrazów obcych z przykładami i poradami (2012), Wydawnictwo Naukowe PWN, Warszawa.

Sternberg, R.J. (1993), „The concept of "giftedness": a pentagonal implicit theory”, in: Bock, G.R., Ackrill, K. (Ed.), The Origins and Development of High Ability, Ciba Foundation Symposium 178, John Wiley \& Sons, Chichester, pp. 5-21.

Strack, R., Caye, J.M., Lassen, S., Bhalla, V., Puckett, J., Espinosa, E., Francoeur, F., Haen P. (2010), „Creating People Advantage 2010. How Companies Can Adapt Their HR Practices for Volatile Times", retrieved from: http://www.bcg.com/expertise_impact/ publications/PublicationDetails.aspx?id=tcm:12-61341.

Suchodolski, B. (1974), Kim jest człowiek, Wiedza Powszechna, Warszawa.

Tansley, C. (2011), „What do we mean by the term „talent” in talent management?”, Industrial and Commercial Training, Vol. 43 No. 5, pp. 266-274.

DOI: $10.1108 / 00197851111145853$ 